\title{
Purification of bacteriophage M13 by anion exchange chromatography
}

\begin{abstract}
M13 is a non-lytic filamentous bacteriophage (phage). It has been used widely in phage display technology for displaying foreign peptides, and also for studying macromolecule structures and interactions. Traditionally, this phage has been purified by cesium chloride $(\mathrm{CsCl})$ density gradient ultracentrifugation which is highly laborious and time consuming. In the present study, a simple, rapid and efficient method for the purification of M13 based on anion exchange chromatography was established. A pre-packed SepFast ${ }^{\mathrm{TM}}$ Super Q column connected to a fast protein liquid chromatography (FPLC) system was employed to capture released phages in clarified Escherichia coli fermented broth. An average yield of $74 \%$ was obtained from a packed bed mode elution using citrate buffer ( $\mathrm{pH} 4)$, containing $1.5 \mathrm{M} \mathrm{NaCl}$ at $1 \mathrm{ml} / \mathrm{min}$ flow rate. The purification process was shortened substantially to less than $2 \mathrm{~h}$ from $18 \mathrm{~h}$ in the conventional ultracentrifugation method. SDS-PAGE revealed that the purity of particles was comparable to that of $\mathrm{CsCl}$ gradient density ultracentrifugation method. Plaque forming assay showed that the purified phages were still infectious.
\end{abstract}

Keyword: Filamentous bacteriophage; Virus purification; Anion exchange chromatography; Fast protein liquid chromatography; Cesium chloride centrifugation 